this alteration has not occurred spontaneously a period on insulin treatment might induce the requisite adaptation.

\section{Summary}

In seven patients with the post-gastrectomy dumping syndrome a pre-cibal injection of insulin was shown to reduce the post-cibal fall in plasma volume, at the same time relieving their symptoms.

Thirty-three patients with the dumping syndrome were treated with insulin before one or two meals a day. All but three showed some benefit, though in only 14 was this definite: of these, six were able, after a while, to give up treatment without relapse.

The possible mechanism by which insulin achieves these effects is discussed. In patients with the dumping syndrome it appears that their carbohydrate metabolism has failed to adapt to the new circumstances produced by the operation.

It is concluded that insulin treatment is of benefit in some patients with the dumping syndrome.

\section{REFERENCES}

Castenfors, M. L. (1961). Scand. J. clin. Lab. Invest., 13, Suppl. 62.

Glaessner, C. L. (1940). Rev. Gastroent., 7, 528.

Hobsley, M., and Le Quesne, L. P. (1960). Brit. med. J., 1, 147. Le Quesne, L. P., Hobsley, M., and Hand, B. H. (1960). Ibid., 1,141 .

Machella, T. E. (1949). Ann. Surg., 130, 145.

Nabarro, J. D. N. (1962). In press.

Roberts, K. E., Randall, H. T., Farr, H. W., Kidwell, A. P McNeer, G. P., and Pack, G. T. (1954)." Ann. Surg., 140", 631.

Webber, B. M., Bender, M. A., and Moore, G. E. (1957). New Engl. med. J., 256, 285.

\title{
BLOOD GROUPS AND ENZYMES OF HUMAN RED CELLS AFTER A YEAR'S STORAGE IN LIQUID NITROGEN
}

BY

R. G. HUNTSMAN, M.B., B.Chir., M.R.C.P.

Chemical Pathologist, Memorial Hospital, Peterborough, Northants

ELIZABETH W. IKIN, B.Sc.

Senior Scientific Officer, Medical Research Council, Blood Group Reference Laboratory, Lister Institute, London
B. A. L. HURN, M.B., B.S.

Registrar, Department of Pathology, Lewisham Hospital, London

H. LEHMANN, M.D., Sc.D., M.R.C.P., F.R.I.C. Reader in Chemical Pathology, St. Bartholomew's Hospital, London

J. LIDDELL, M.A., M.D.

Senior Registrar, Nuffield Department of Clinical

Biochemistry, Radcliffe Infirmary, Oxford

The identification of blood-group antibodies in human sera is usually performed in specialized laboratories. Much of this work could be done in routine laboratories were it not for the practical difficulty of keeping the necessary panel of red cells of known antigen constitution. At present they are preserved in glycerol at about -15 to $-20^{\circ}$ C. (or very occasionally at $-40^{\circ} \mathrm{C}$.), a technique introduced by Smith (1950) and developed by Crawford, Cutbush, and Mollison (1954). Glycerol-preserved cells cannot be stored in an ordinary deep-freeze for much more than one year because of progressive haemolysis. Moreover, the thawing of the cells and removal of the glycerol is slow and tedious.

An alternative procedure is the storage of red cells in liquid nitrogen. In this technique the freezing and thawing is rapid enough to avoid gross injury to the red cell. Additional protection is given if suitable sugars are added to the blood before freezing (Meryman and Kafig, 1955 ; Huntsman, Hurn, and Lehmann, 1960 ; Strumia, Colwell, and Strumia, 1960). These substances, unlike glycerol, are easy to remove after thawing. Originally the technique was developed for the preservation of blood for transfusion, but many of the practical difficulties are still unsolved. This aspect of work on storage in liquid nitrogen has been reviewed recently by Lehmann and Hurn (1961) and Hurn, Huntsman, and Lehmann (1962). Huntsman et al. (1960, 1962) suggested that the simplicity of the method made it highly suitable for serological work and showed that it had no adverse effect on the range of red-cell antigens tested. Bronson and McGinniss (1962) reported good preservation of agglutinogens after six months' storage.

The present paper provides a practical system for the freezing, storing, and recovery of red cells and shows the effect of one year's storage on the antigenic structure and percentage haemolysis. The biochemical integrity of the red cells has also been investigated by the serial estimation of four intracellular enzymes over the same period.

\section{Apparatus}

Cabinet for Liquid-nitrogen Storage.-Type L.N.R. $25 \mathrm{~B}$, made by the Linde Company (a branch of Union Carbide Co.), is supplied with six canisters (Fig. 1) which require further modification (Figs. 2 and 3). The cells are kept in cardboard boxes ("corruganza" seamless ointment boxes, new No. 20 size), eight of which can be kept in each canister (Fig. 3). They are labelled as required on their lids and sides with a grease pencil. To label a box while it is cold, a "magic marker" should be used. The canisters should be kept full of boxes, even if some of the latter are empty. The cabinet needs replenishing with liquid nitrogen at intervals of about one to two weeks. If no reserve supply of liquid nitrogen is kept in a separate Dewar flask a simple ladle for removing small amounts of nitrogen from the main storage cabinet will be required. A thin-walled longhandled ladle is most suitable. This is manufactured by welding a bottom and handle to a metal cylinder $5 \mathrm{~cm}$. in diameter and $10 \mathrm{~cm}$. in length.

\section{Method}

Preparation of Blood.-Whole blood was treated with anticoagulant by the addition of $1 \mathrm{mg}$. of ethylenediamine tetra-acetic acid (E.D.T.A.) per each $\mathrm{ml}$. The sodium, potassium, or lithium salt of E.D.T.A. is equally satisfactory. The blood should be frozen within one or two days of collection. Not longer than two hours before freezing, the blood is mixed with half its volume 
of $40 \%$ sucrose in distilled water. Domestic granulated sugar is satisfactory.

\section{Freezing Prepared Blood}

This is a slow process, but can be left unattended. A glass funnel of suitable size is connected to a piece of

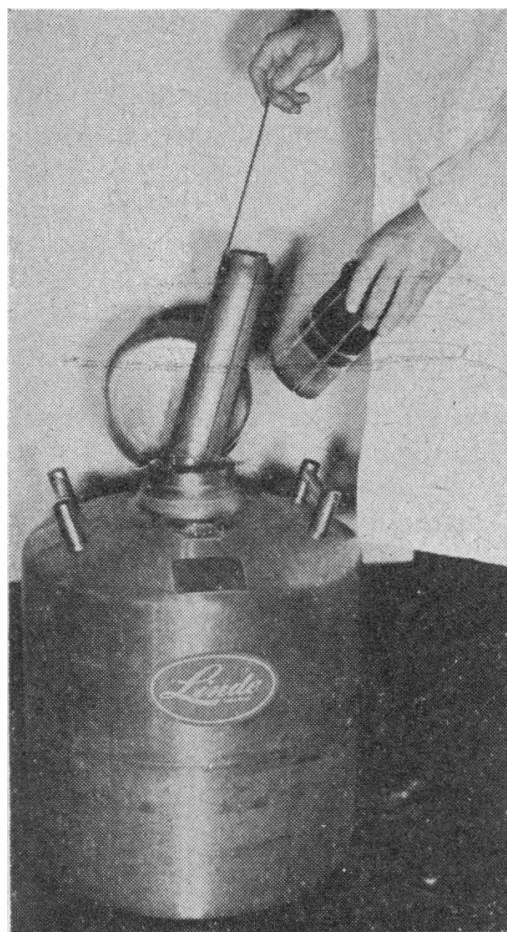

Fio. 1.-Refrigerator. One of the six canisters being removed.

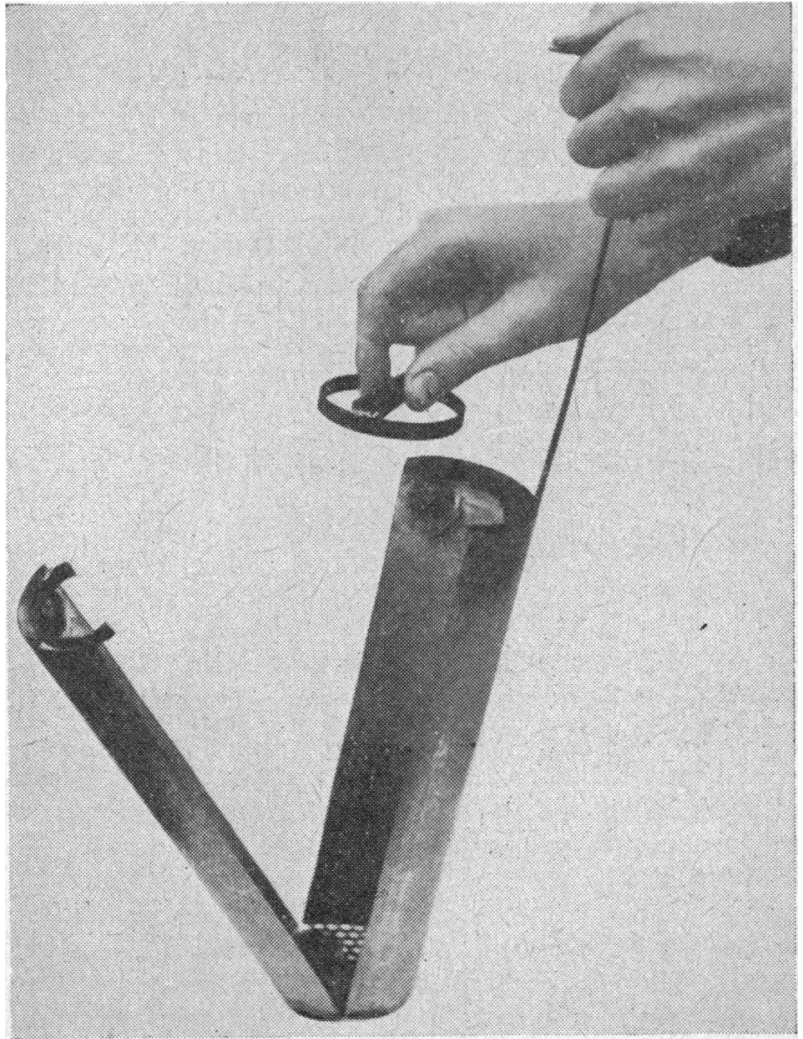

Fio. 2.-Modification of canister to permit easy handling of stored specimens. Note hinge at bottom and lock ring. it drips into the nitrogen each drop floats for a few seconds before sinking to the bottom as a frozen pellet 2-3 $\mathrm{mm}$. in diameter. If the blood drips too fast the floating drops will stick together. The rate may be adjusted by a clip or by raising or lowering the funnel in relation to the needle tip so as to obtain the maximum rate compatible with reasonably discrete pellet formation. The final rate of freezing is of the order of 1 to $2 \mathrm{ml} . / \mathrm{min}$.

It is convenient to modify the method for very small or very large quantities. For less than $20 \mathrm{ml}$. of blood it is less wasteful to drip the blood by hand from a syringe into a smaller beaker, while for more than $100 \mathrm{ml}$. a used Fenwal plastic blood-transfusion pack with its attached tubing can be washed and substituted for the funnel and tube. The Fenwal tubing fits snugly into the socket of a Luer fitting needle.

Whatever system is used the level of the liquid nitrogen should be periodically inspected. The blood in the funnel can be occasionally stirred to prevent sedimentation of the red cells. After freezing the required quantity of blood, the greater part of the excess liquid nitrogen is decanted and the frozen pellets are then transferred with a cooled spoon to the cardboard boxes, already half filled with liquid nitrogen. The pellets must remain immersed in the liquid throughout this procedure. The boxes are then filled to the brim with hiquid nitrogen, placed in an appropriate canister, and inserted in the liquid-nitrogen refrigerator.

\section{Removal and Thawing of Specimens}

The canister is withdrawn from the storage cabinet and opened as shown in Fig. 3. The cardboard box is removed by hooking a fingernail under the edge of its lid, the containers above and below being restrained by thumb and second finger respectively if necessary. As

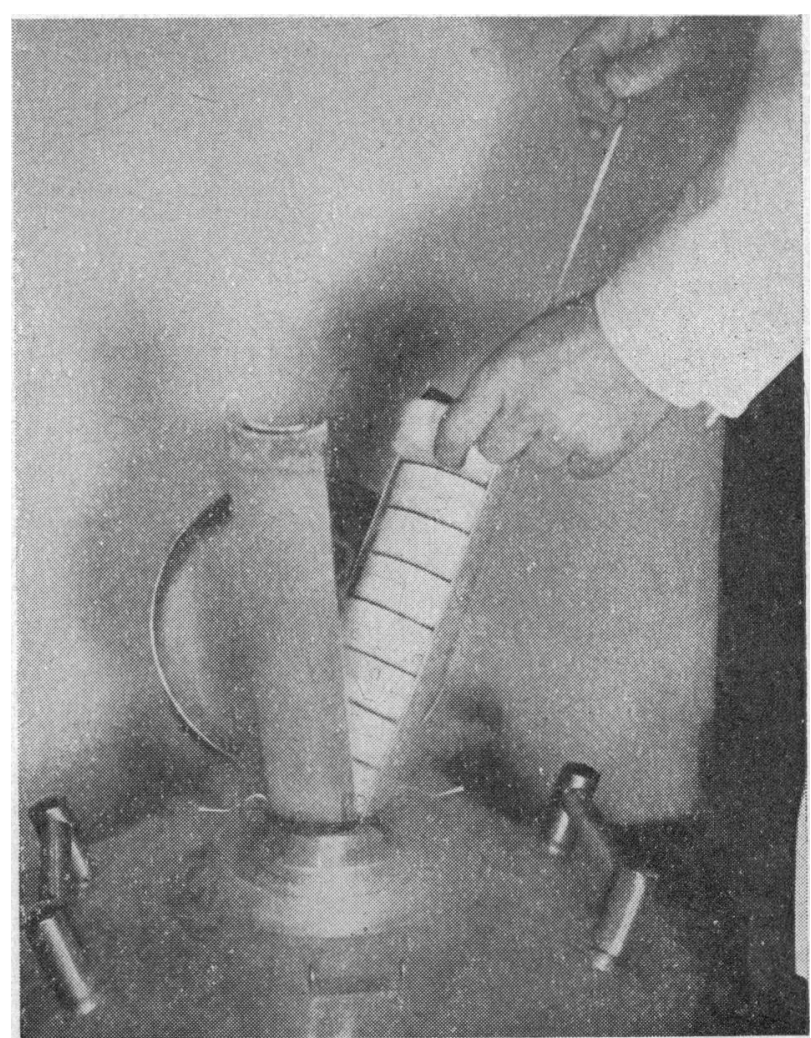

FIo. 3.-Canister with its complement of eight ointment boxes. 
soon as it has moved a little way it can be grasped more firmly and removed to the bench. The canister is then closed and immediately returned to the refrigerator.

The lid is removed from the box, which is immediately filled with liquid nitrogen from a beaker or vacuum flask previously prepared (this may not be necessary if the box bas come from the bottom of the storage cabinet). A teaspoon is cooled by dipping into the nitrogen in the beaker and is then used to remove the desired amount of frozen pellets from the box. Some liquid nitrogen will necessarily be removed as well, but this is drained off against the wall of the box. If it is not removed a good deal of spluttering will occur during the next stage.

The now dry pellets of frozen blood are tipped immediately into a suitable tube containing at least ten times their volume of $1 \% \mathrm{NaCl}$ solution at $43-45^{\circ} \mathrm{C}$. The tube is closed with the thumb and shaken, and the pellets melt within a few seconds. As soon as the specimen has been thawed the box is replaced in the storage cabinet. The tubes are centrifuged and the cells washed as often as desired in physiological saline at room temperature before use.

\section{Other Methods Used in the Present Study}

\section{Recovery of Intact Cells After Thawing}

Test-tubes 4 by $\frac{5}{8}$ in. ( 10 by $1.6 \mathrm{~cm}$.) were graduated at about $10 \mathrm{ml}$. and filled accurately to the mark with saline at $45^{\circ} \mathrm{C}$. Six to ten pellets of frozen blood were dropped into the saline and quickly melted by vigorous shaking. The tubes were then centrifuged and the coloured supernatant was removed and retained. The intact cells were then haemolysed by adding distilled water accurately to the mark and centrifuging after a few minutes to remove stroma.

The haemoglobin content of the supernatant and of the haemolysate were read in a Unicam SP 500 colorimeter, using an Ilford No. 404 green filter, for which a calibration curve using known dilutions of haemoglobin had previously been prepared. Then:

$\%$ of intact cells $=\frac{\mathrm{Hb} \text { in haemolysate }}{\mathrm{Hb} \text { in supernatant }+\mathrm{Hb} \text { in haemolysate }} \times 100$

All estimates were performed in duplicate.

\section{Enzyme Estimations}

Blood for enzyme and serological tests was thawed separately from the few pellets required for estimating cell recovery. After thawing, the cells were washed three times in $0.85 \%$ saline and the packed cells were used for enzyme assays. The haemoglobin concentration of the packed cell mass was estimated by reading the optical density of a suitable dilution in $0.04 \%$ ammonia solution. Results have been expressed throughout as units/mg. of haemoglobin, owing to the variable amount of wash fluid trapped in the packed cells.

Glutamic Oxaloacetic Transaminase.-A 1 in 10 dilution of the packed red cells in distilled water was made. The transaminase activity was measured by the colorimetric method of Reitman and Frankel (1957).

Aldolase.-Aldolase activity was determined on a 1 in 40 dilution of the packed red cells. The method used was that provided by C. F. Boehringer and Soehne, GmbH, Mannheim, Germany, based on the method of Bruns (1954).

Glucose-6-phosphate Dehydrogenase and 6-Phosphogluconate Dehydrogenase.-These were measured simul- taneously by a method adapted from that of A. G. Motulsky (personal communication, 1960). The final reaction mixtures contained: Total volume $3 \mathrm{ml}$. Packed washed cells $8 \mu \mathrm{l}$. Trishydroxymethylaminomethane $0.74 \mathrm{~m}$-mole buffered to $p \mathrm{H} 8.5$ with $\mathrm{HCl}$. Disodium E.D.T.A. $3.3 \mu$ mole. Magnesium chloride $10 \mu$ mole. Nicotinamide $40 \mu$ mole. Triphosphopyridine nucleotide sodium salt $0.4 \mathrm{mg}$. 6-Phosphogluconate $5 \mu$ mole.

Glucose-6-phosphate $5 \mu$ mole was added to this reaction mixture for determination of the glucose-6phosphate dehydrogenase activity.

The dehydrogenase activity was estimated at room temperature by observation of the increase in optical density at $340 \mathrm{~m} \mu$ due to reduction of T.P.N. The values, expressed as optical density units, have been corrected to a standard temperature of $23^{\circ} \mathrm{C}$. by applying the factor determined by Glock and McLean (1953). Glucose-6-phosphate dehydrogenase activity was taken as the difference in the readings obtained with and without the addition of glucose-6-phosphate to the standard reaction mixture containing 6-phosphogluconate.

\section{Blood-Group Estimations}

Each of the seven bloods used was examined for the antigens of the ABO, rhesus, MNS, P, Lutheran, Kell, Lewis, and Duffy blood-group systems. Qualitative changes were sought by repeating these tests on subsequent samples, but no changes were found. Quantitative changes were examined by titrating the antisera which gave positive results against the samples and against freshly drawn control cells which, with a few unavoidable exceptions, were taken from the same persons on every occasion. The results of the titrations were calculated in terms of "scores" as recommended by Race and Sanger (1950).

\section{Results}

1. Recovery of Intact Cells. - The results are shown in Table I. It can be seen that there was no significant

$$
\text { TABLE I.-Percentage Recovery of Intact Red Cells After }
$$
Storage in Liquid Nitrogen

\begin{tabular}{|c|c|c|c|c|c|c|c|}
\hline $\begin{array}{c}\text { Speci- } \\
\text { men }\end{array}$ & $\begin{array}{c}\text { Imme- } \\
\text { diate }\end{array}$ & Week & $\stackrel{1}{\text { Month }}$ & $\stackrel{2}{2}$ & $\begin{array}{c}3 \\
\text { Months }\end{array}$ & $\begin{array}{c}6 \\
\text { Months }\end{array}$ & $\begin{array}{c}1 \\
\text { Year }\end{array}$ \\
\hline $\begin{array}{l}\mathbf{A} \\
\mathbf{B} \\
\mathbf{C} \\
\mathbf{D} \\
\mathbf{E} \\
\mathbf{F} \\
\mathbf{G} \\
\mathbf{H}\end{array}$ & $\begin{array}{l}86 \\
91 \\
93 \\
93 \\
91 \\
94 \\
= \\
\end{array}$ & $\begin{array}{l}93 \\
92 \\
93 \\
92 \\
94 \\
94\end{array}$ & $\begin{array}{l}92 \\
92 \\
92 \\
85 \\
88 \\
\overline{90}\end{array}$ & $\begin{array}{l}91 \\
92 \\
91 \\
94 \\
93 \\
94 \\
\end{array}$ & $\begin{array}{l}93 \\
94 \\
93 \\
\frac{\overline{9}}{94} \\
=\end{array}$ & $\begin{array}{l}91 \\
90 \\
87 \\
93 \\
91 \\
93 \\
93 \\
97 .\end{array}$ & $\begin{array}{l}95 * \\
944^{*} \\
933^{*} \\
96^{*} \\
94^{*} \\
93^{*} \\
-\end{array}$ \\
\hline
\end{tabular}

* These sp cimens were thawed with $1 \%$ saline. An others were thawed with $0.85 \%$ saline.

change in recovery in the course of a year. There was a slight improvement when thawing was carried out in $1 \%$ saline rather than $0.85 \%$ saline.

2. Enzyme Values.-The results are shown in Tables II to $\mathrm{V}$; the mean values, expressed as a percentage of the level before freezing, are shown graphically in Fig. 4. The serum aldolase gradually declined to less than $60 \%$ of the original value over the course of the year. There was a slight decrease in the transaminase content, while the dehydrogenase changes were erratic and showed no steady change with time, other than the rather consistent increase in activity which follows on the freeze-thaw process itself. 
3. Blood-group Antigens.-The grouping properties of the seven bloods examined are given in Table VI and the titration scores of these blood samples at intervals over a period of 14 months are tabulated in Table VII. The titration scores indicate some loss of titre, and there was also some loss of activity, as shown by the strength of reaction of the red cells with undiluted serum. It will be noted that occasionally a grouping serum had deteriorated a little, but this is shown in the control blood as well. Blood 6 with rhesus blood group $D^{u}$ is interesting, as the reactions in saline with anti-D certainly decreased, but the reactions by the antiglobulin test with an albumin anti-D stayed very constant, being always a little better than those of the control. The $\mathrm{P}_{\mathbf{1}^{-}}$reactions of the same blood also seemed to get weaker. In no case was the avidity so reduced as to make it difficult to interpret the results, and the preliminary "run through of all groups," which always included the Lewis groups, never showed any change in these. No titration was carried out with anti-Lewis sera owing to the unreliable character of such antisera.

\section{Discussion}

It is clear that the present method will preserve cells intact for a long period of time and that the antigenic reactions of the cells used in this series of tests

TABLE VI.-Grouping Properties of the Seven Chosen Blood Sumples

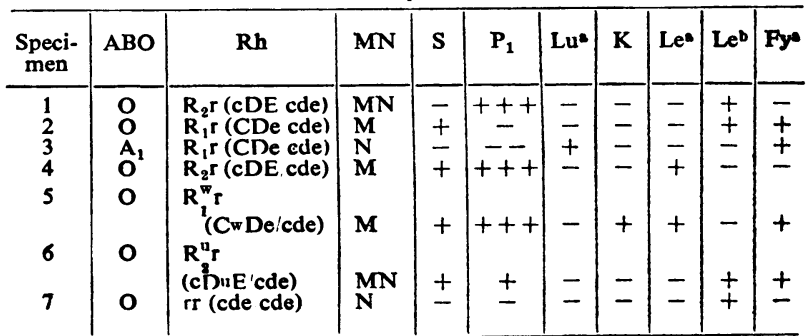

TABLE II.-Aldolase Content in Units/mg. Hb of Red Cells Before and After Storage in Liquid Nitrogen. Figures in Parentheses Represent \% Survival of Enzyme

\begin{tabular}{|c|c|c|c|c|c|c|c|c|}
\hline Specimen & $\begin{array}{c}\text { Before } \\
\text { Freezing }\end{array}$ & $\begin{array}{l}\text { Immediately } \\
\text { after Freezing }\end{array}$ & ${ }_{\text {Week }}^{1}$ & $\stackrel{1}{\text { Month }}$ & $\stackrel{2}{2}$ & $\stackrel{3}{\text { Months }}$ & $\begin{array}{c}6 \\
\text { Months }\end{array}$ & $\begin{array}{c}1 \\
\text { Year }\end{array}$ \\
\hline $\begin{array}{l}\mathbf{A} \\
\mathbf{B} \\
\mathbf{C} \\
\mathbf{D} \\
\mathbf{E} \\
\mathbf{F} \\
\mathbf{G} \\
\mathbf{H}\end{array}$ & $\begin{array}{l}2 \cdot 3 \\
2 \cdot 9 \\
2 \cdot 7 \\
3 \cdot 0 \\
2 \cdot 4 \\
2 \cdot 8 \\
2 \cdot 2 \\
2 \cdot 4\end{array}$ & $\begin{array}{c}2 \cdot 2(95) \\
2 \cdot 7(93) \\
2 \cdot 6(96) \\
2 \cdot 8(94) \\
1 \cdot 8(75) \\
2 \cdot 3(82) \\
=\end{array}$ & $\begin{array}{l}2 \cdot 1(91) \\
2.6(90) \\
2 \cdot 5(93) \\
2.4(80) \\
1.2(50) \\
2.4(86) \\
2.0(91)\end{array}$ & $\begin{array}{c}1 \cdot 9(83) \\
2 \cdot 3(80) \\
2 \cdot 2(81) \\
2 \cdot 5(82) \\
1 \cdot 7(71) \\
= \\
2 \cdot 2(92)\end{array}$ & $\begin{array}{l}1.9(83) \\
2.4(83) \\
2.3(85) \\
2.5(82) \\
1.7(71)) \\
2.0(91)\end{array}$ & $\begin{array}{c}1 \cdot 9(83) \\
2 \cdot 4(83) \\
2 \cdot 3(85) \\
\overline{=} \\
2 \cdot 2(79) \\
=\end{array}$ & $\begin{array}{l}1 \cdot 5(65) \\
2 \cdot 1(72) \\
2 \cdot 2(81) \\
2 \cdot 2(73) \\
1.6(67) \\
2.1(75) \\
1.9(86) \\
1.9(80)\end{array}$ & $\begin{array}{c}1.0(44) \\
1.6(55) \\
2.0(74) \\
1.7(57) \\
1.4(58) \\
1.9(68) \\
1.5(68) \\
\end{array}$ \\
\hline Mean $\%$ survival & & 89 & 89 & 81 & 82 & 82 & 75 & 59 \\
\hline
\end{tabular}

TABle III.-Glutamic Oxaloacetic Transaminase Content in Units/mg. Hb of Red Cells Before and After Storage in Liquid Nitrogen. Figures in Parentheses Represent \% Survival of Enzyme

\begin{tabular}{|c|c|c|c|c|c|c|c|c|}
\hline Specimen & $\begin{array}{c}\text { Before } \\
\text { Freezing }\end{array}$ & $\begin{array}{l}\text { Immediately } \\
\text { after Freezing }\end{array}$ & $\begin{array}{c}1 \\
\text { Week }\end{array}$ & Month & Months & Months & $\begin{array}{c}6 \\
\text { Months }\end{array}$ & $\begin{array}{c}1 \\
\text { Year }\end{array}$ \\
\hline $\begin{array}{l}\mathbf{A} \\
\mathbf{B} \\
\mathbf{C} \\
\mathbf{D} \\
\mathbf{E} \\
\mathbf{F} \\
\mathbf{G} \\
\mathbf{H}\end{array}$ & $\begin{array}{l}1.8 \\
3.4 \\
3.4 \\
3.6 \\
2.9 \\
3.2 \\
4.9 \\
4.8\end{array}$ & $\begin{array}{c}1.7(95) \\
3.3(97) \\
3.3(97) \\
3.4(95) \\
2.8(97) \\
3.0(94) \\
=\end{array}$ & $\begin{array}{l}1 \cdot 6(90) \\
3 \cdot 2(94) \\
3 \cdot 2(92) \\
3 \cdot 0(83) \\
2 \cdot 2(76) \\
3.0(94) \\
4 \cdot 6(94) \\
-\end{array}$ & $\begin{array}{c}1.5(84) \\
2.9(85) \\
3.0(88) \\
3.1(86) \\
2.4(83) \\
\overline{-} \\
4.6(96)\end{array}$ & $\begin{array}{c}1.5(84) \\
2.9(85) \\
3.0(88) \\
3.0(83) \\
2.4(83) \\
4.5(92) \\
-\end{array}$ & $\begin{array}{c}1.5(84) \\
2.9(85) \\
3.0(88) \\
\overline{-} \\
2.9(91) \\
=\end{array}$ & $\begin{array}{l}1.4(78) \\
2.7(79) \\
2.9 \\
3.1(85) \\
2.4(83) \\
3.0(94) \\
4.3(88) \\
4.4(92)\end{array}$ & $\begin{array}{c}1.5(84) \\
2.7(79) \\
2.7(79) \\
3.0(83) \\
2.5(86) \\
3.1(97) \\
3.9(80) \\
-\end{array}$ \\
\hline Mean $\%$ survival & & 96 & 91 & 87 & 86 & 87 & 86 & 84 \\
\hline
\end{tabular}

TABLE IV.-Glucose-6-phosphate Dehydrogenase Content in Units/mg. Hb of Red Cells Before and After Storage in Liquid Nitrogen. Figures in Parentheses Represent \% Survival of Enzyme

\begin{tabular}{|c|c|c|c|c|c|c|c|c|}
\hline Specimen & $\begin{array}{c}\text { Defore } \\
\text { Preezing }\end{array}$ & $\begin{array}{l}\text { Immediately } \\
\text { after Freezing }\end{array}$ & $\begin{array}{c}1 \\
\text { Week }\end{array}$ & $\stackrel{1}{\text { Month }}$ & $\stackrel{2}{\text { Months }}$ & $\stackrel{3}{\text { Months }}$ & $\begin{array}{c}6 \\
\text { Months }\end{array}$ & $\stackrel{1}{\text { Year }}$ \\
\hline $\begin{array}{l}\mathbf{A} \\
\mathbf{B} \\
\mathbf{C} \\
\mathbf{D} \\
\mathbf{E} \\
\mathbf{F} \\
\mathbf{G} \\
\mathbf{H}\end{array}$ & $\begin{array}{l}81 \\
76 \\
61 \\
80 \\
76 \\
75 \\
74 \\
67\end{array}$ & $\begin{array}{c}76(94) \\
81(107) \\
88(144) \\
88(110) \\
94(124) \\
93(124) \\
=\end{array}$ & $\begin{array}{l}65(80) \\
89(117) \\
93(152) \\
84(105) \\
91(120) \\
89(119) \\
79(107) \\
-\end{array}$ & $\begin{array}{l}68(84) \\
75(99) \\
90(147) \\
84(105) \\
91(120) \\
= \\
74(110)\end{array}$ & $\begin{array}{c}89(110) \\
80(105) \\
90(147) \\
75(94) \\
93(122) \\
79(107) \\
-\end{array}$ & $\begin{array}{c}75(93) \\
73(96) \\
92(151) \\
= \\
90(120) \\
=\end{array}$ & $\begin{array}{r}86(106) \\
72(95) \\
83(136) \\
103(129) \\
110(145) \\
98(131) \\
62(84) \\
85(127)\end{array}$ & $\begin{array}{c}84(104) \\
94(124) \\
83(136) \\
82(102) \\
89(117) \\
73(97) \\
70(95) \\
-\end{array}$ \\
\hline Mean $\%$ survival & & 117 & 114 & 111 & 114 & 115 & 119 & 111 \\
\hline
\end{tabular}

TABLE V.-6-Phosphogluconate Dehydrogenase Content in Units/mg. Hb of Red Cells Before and After Storage in Liquid Nitrogen. Figures in Parentheses Represent \% Survival of Enzyme

\begin{tabular}{|c|c|c|c|c|c|c|c|c|}
\hline Specimen & $\begin{array}{l}\text { Before } \\
\text { Preezing }\end{array}$ & $\begin{array}{l}\text { Immediately } \\
\text { after Freezing }\end{array}$ & $\begin{array}{l}1 \\
\text { Week }\end{array}$ & $\stackrel{1}{\text { Month }}$ & $\stackrel{2}{2}$ & $\stackrel{3}{\text { Months }}$ & $\stackrel{6}{\text { Months }}$ & $\begin{array}{c}1 \\
\text { Year }\end{array}$ \\
\hline $\begin{array}{l}\mathbf{A} \\
\mathbf{B} \\
\mathbf{C} \\
\mathbf{D} \\
\mathbf{E} \\
\mathbf{F} \\
\mathbf{G} \\
\mathbf{H}\end{array}$ & $\begin{array}{l}45 \\
44 \\
51 \\
49 \\
54 \\
42 \\
46 \\
51\end{array}$ & $\begin{array}{c}47(104) \\
45(102) \\
59(116) \\
52(106) \\
56(104) \\
50(119) \\
=\end{array}$ & $\begin{array}{c}44(88) \\
51(116) \\
57(112) \\
53(108) \\
50(93) \\
42(100) \\
44(96) \\
-\end{array}$ & $\begin{array}{l}44(88) \\
44(100) \\
46(90) \\
52(106) \\
56(104) \\
- \\
38(74)\end{array}$ & $\begin{array}{c}51(113) \\
49(111) \\
53(104) \\
44(90) \\
46(85) \\
46(100) \\
-\end{array}$ & $\begin{array}{c}48(107) \\
46(105) \\
52(102) \\
- \\
39 \text { (93) } \\
=\end{array}$ & $\begin{array}{l}45(100) \\
44(100) \\
47(92) \\
43(88) \\
43(80) \\
37(88) \\
44(96) \\
61(120)\end{array}$ & $\begin{array}{c}52(116) \\
53(120) \\
65(128) \\
55(112) \\
55(102) \\
48(112) \\
59(128) \\
-\end{array}$ \\
\hline Mean $\%$ survival & & 108 & 102 & 94 & 100 & 102 & 95 & 117 \\
\hline
\end{tabular}


deteriorated only slightly, and certainly no more than would have been expected with cells stored in glycerol for a similar period. In no case was the avidity so reduced after one year's storage as to make it difficult to interpret the results of standard blood-grouping tests.

It is undoubtedly true that cells can be recovered much more rapidly and simply than they can after storage with glycerol, but anyone who has not worked

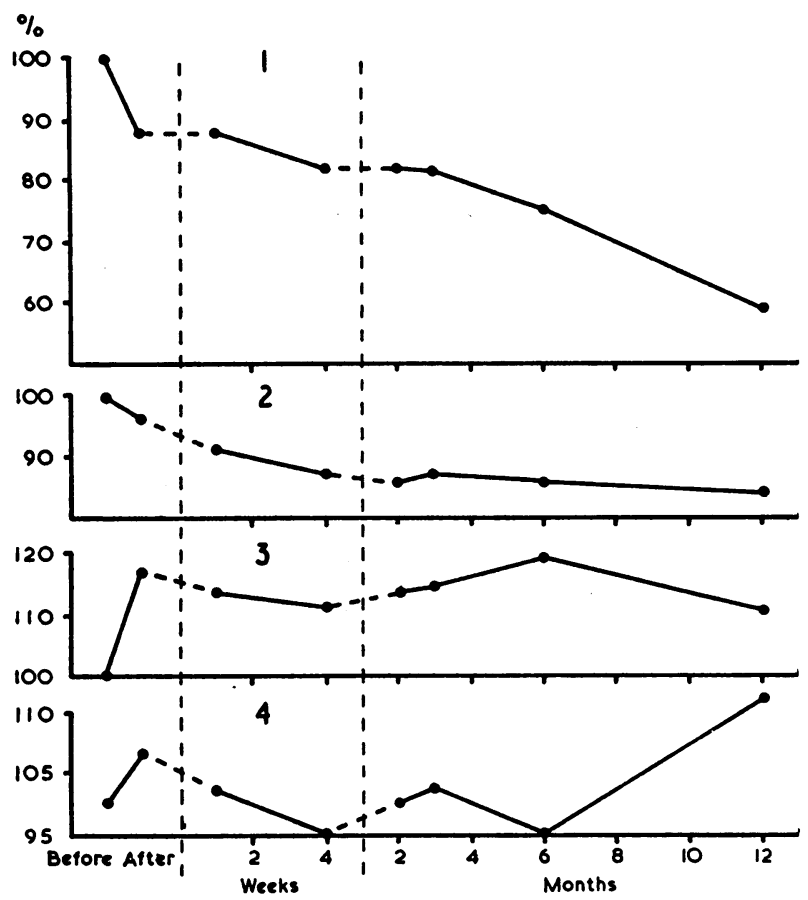

Fig. 4.-Enzyme activity of red cells during one year's storage in liquid nitrogen. Result expressed as a percentage of the level aminase. 3, Glucose-6-phosphate dehydrogenase. 4, 6-Phosphogluconate dehydrogenase.

with liquid nitrogen may well wonder whether the question of expense and apparent difficulties of handling may not outweigh the advantages to be gained. Although liquid nitrogen boils at $-196^{\circ} \mathrm{C}$. no harm results from direct contact with the skin for a second or two, since an insulating layer of gas is formed immediately. However, there is no such protection if a non-volatile object at $-196^{\circ} \mathrm{C}$. is handled, and if such an object has a high heat capacity and good thermal conductivity (brass or copper, for instance) quite severe freezing injury might occur almost instantaneously. These materials are therefore best avoided. On the other hand, an object of poor thermal conductivity (such as the waxed cardboard boxes used in the present method) is safe to touch with bare hands for a short period. Thus when the boxes are being removed from the storage cabinet this should stand within reach of the bench. The metal canisters themselves are made of stainless steel, which has a very poor thermal conductivity for a metal, and the modified canisters can be safely opened with bare fingers. The lock rings (Fig. 2), which must be home-made, are unlikely to be of stainless steel, and it is important that they should be freefitting and have their cross-pieces insulated with a piece of split plastic tubing. Two other rather remote dangers must be avoided: spilt liquid nitrogen must not be trapped in clothing, and adequate ventilation must be assured to avoid replacement of atmospheric oxygen by the evaporating nitrogen. Gloves have not been worn by us, but it might be reasonable to wear safety spectacles. No injury has occurred to any member of the team during the many manipulations involving liquid nitrogen in this study. The liquid nitrogen appears much less dangerous than strong acids, which are regularly handled by junior technical staff.

The cost is more than that of the glycerol method using a standard deep freeze, but much less than that of electrical refrigeration at temperatures below $-20^{\circ} \mathrm{C}$. The storage cabinet, which is big enough for the purposes of an ordinary laboratory, costs about $£ 200$ (the canister modification may cost another few pounds). With an expensive cabinet having limited storage space there must be a high specimen/container bulk ratio, and the system here reported has been developed in an attempt to combine this with ease of handling. Liquid nitrogen is used at the rate of 1-2 1. per day (1.75-3.5 lb. per day); the cost for small quantities is $1 \mathrm{~s}$. $6 \mathrm{~d}$. per pound, when supplied by the British Oxygen Company. There may be difficulties about obtaining supplies in isolated parts of the country. Liquid nitrogen will be available wherever liquid oxygen is manufactured.

The results of the enyzme estimations show a perceptible loss of activity of aldolase and to a less extent of glutamic oxaloacetic transaminase over the year, while the dehydrogenases show no such loss. This is the usual pattern seen on storage as distinct from in-vivo ageing of the red cell as described by Rapoport (1961). Our results indicate that complete stability of biological systems cannot be expected even at the very low temperature of $-196^{\circ} \mathrm{C}$. The implications of this are of some interest in the light of recent advances in the freezing of entire organisms (Smith, 1961).

The results obtained with both dehydrogenases showed substantial variations from one time to another, certainly greater than the inherent errors associated with the method. The increase in activity caused by the freeze-thaw process (most pronounced in the case of the glucose-phosphate dehydrogenase) is almost certainly genuine. The dehydrogenases are associated with the stromal fraction of erythrocytes, however, and it is possible that the packed cell mass obtained after thawing would be contaminated with a certain amount of stroma from the lysed cells. Since the enzyme activities are necessarily expressed as a function of haemoglobin content of the cell mass, contamination with stroma would give a falsely high value for the dehydrogenases. As no rigorous attempt was made to standardize the conditions of thawing for the large quantities of blood required for the serological and enzyme tests the possibility could not be excluded that stromal contamination might have varied from one test to another, accounting not only for the general increase in enzyme activity but also its variability.

\section{Summary}

The method of storage in liquid nitrogen after rapid freezing has been adapted to the preservation of red cells for blood-group reference purposes. Blood is anticoagulated with E.D.T.A. and mixed with half its volume of $40 \%$ sucrose. It is frozen by dripping into liquid nitrogen and subsequently thawed in warm saline. By this method more than $90 \%$ of cells can be recovered intact immediately after freezing, and this recovery rate has been maintained for over one year. A practicable system is presented for preparing the frozen droplets and 
storing them in small cardboard containers in a suitable liquid-nitrogen cabinet. The method minimizes handling difficulties and enables full use of limited storage space.

A representative panel of blood group agglutinogens has been observed for more than one year. During this period a fall in avidity and titration scores of certain agglutinogens has been observed, but it has always remained possible to demonstrate all blood groups. Their preservation was at least as good, if not better, as is generally seen after storage in glycerol, and time alone

TABLE VII.-Titration Scores of Blood-group Antigens Before and Immediately After Freezing and After Storage for Various Periods. Control Values Expressed in Parentheses

Specimen 1

\begin{tabular}{|c|c|c|c|c|c|c|c|}
\hline \multicolumn{2}{|c|}{$\begin{array}{c}\text { Antigen Tested and } \\
\text { Control ( ) }\end{array}$} & H (O) & $D\left(R_{2} r\right)$ & $E\left(R_{2} r\right)$ & $\mathbf{M}(\mathrm{MN})$ & $\mathbf{N}(\mathbf{M N})$ & $\mathbf{P}_{2}\left(\mathbf{P}_{1}+++\right)$ \\
\hline 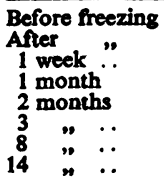 & $\begin{array}{l}\cdots \\
\cdots \\
\cdots \\
\cdots \\
\cdots\end{array}$ & $\begin{array}{l}26(31) \\
24(31) \\
24(32) \\
26(32) \\
24(31) \\
32(31) \\
32(34) \\
26(32)\end{array}$ & $\begin{array}{l}75(82) \\
70(82) \\
70(84) \\
74(84) \\
74(84) \\
75(86) \\
86(84) \\
84(84)\end{array}$ & $\begin{array}{l}57(57) \\
57(57) \\
64(65) \\
64(65) \\
54(57) \\
59(62) \\
57(57) \\
60(62)\end{array}$ & $\begin{array}{l}57(57) \\
57(57) \\
57(59) \\
46(50) \\
53(55) \\
57(57) \\
57(58) \\
55(52)\end{array}$ & $\begin{array}{l}31(33) \\
29(33) \\
24(33) \\
21(26) \\
26(26) \\
24(31) \\
29(31) \\
21(23)\end{array}$ & $\begin{array}{l}24(34) \\
19(34) \\
21(34) \\
21(30) \\
16(24) \\
16(24) \\
16(26) \\
16(27)\end{array}$ \\
\hline
\end{tabular}

Specimen 2

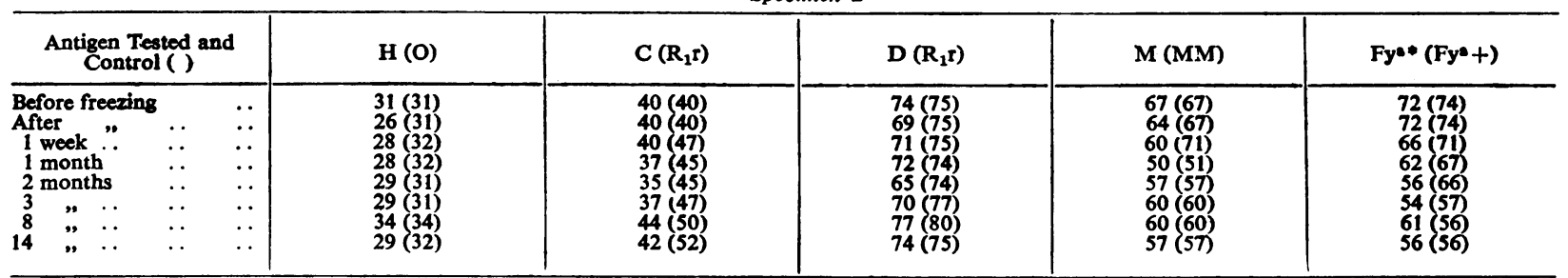

\begin{tabular}{|c|c|c|c|c|c|c|c|}
\hline \multicolumn{8}{|c|}{ Specimen 3} \\
\hline $\begin{array}{l}\text { Antigen Tes } \\
\text { Control }\end{array}$ & ( ) & $\mathbf{A}(\mathbf{A})$ & $C\left(R_{1} r\right)$ & $D\left(R_{1} r\right)$ & $\mathbf{N}(\mathrm{NN})$ & $\mathbf{L y}\left(\mathbf{L} \mathbf{u}^{\star}+\right)$ & $F y^{\star} *\left(F y^{\star}+\right)$ \\
\hline $\begin{array}{l}\text { Before freezing } \\
\text { After } \\
1 \text { week ". } \\
1 \text { month } \\
2 \text { months } \\
\begin{array}{lll}3 & \text { " } & \text {. } \\
8 & \text { " } & \text {. } \\
14 & \text { " } & \text {. }\end{array}\end{array}$ & $\begin{array}{ll}\ldots & \cdots \\
\cdots & \cdots \\
\cdots & \cdots \\
\cdots & \cdots \\
\cdots & \cdots \\
\cdots & \cdots\end{array}$ & $\begin{array}{l}61(61) \\
49(61) \\
57(61) \\
54(61) \\
58(63) \\
56(62) \\
58(60) \\
54(58)\end{array}$ & $\begin{array}{l}44(47) \\
42(47) \\
40(47) \\
40(45) \\
42(45) \\
42(47) \\
45(50) \\
44(52)\end{array}$ & $\begin{array}{l}75(75) \\
74(75) \\
67(75) \\
67(74) \\
70(74) \\
72(77) \\
77(80) \\
74(75)\end{array}$ & $\begin{array}{l}35(35) \\
33(35) \\
34(36) \\
34(36) \\
33(33) \\
33(33) \\
33(33) \\
31(31)\end{array}$ & $\begin{array}{l}27(38) \\
22(38) \\
22(33) \\
27(30) \\
22(30) \\
27(30) \\
35(39) \\
27(30)\end{array}$ & $\begin{array}{l}69(71) \\
66(71) \\
66(71) \\
56(67) \\
54(66) \\
59(57) \\
66(56) \\
64(56)\end{array}$ \\
\hline
\end{tabular}

\begin{tabular}{|c|c|c|c|c|c|c|}
\hline \multicolumn{7}{|c|}{ Specimen 4} \\
\hline $\begin{array}{l}\text { Antigen Tes } \\
\text { Control }\end{array}$ & sted and & $\mathbf{H}(\mathbf{0})$ & $\mathbf{D}\left(\mathbf{R}_{\mathbf{2}} \mathbf{r}\right)$ & $E\left(R_{\mathbf{2}} \mathbf{r}\right)$ & $\mathbf{M}(\mathbf{M M})$ & $\mathbf{P}_{1}\left(\mathbf{P}_{1}+++\right)$ \\
\hline $\begin{array}{l}\text { Before freezing } \\
\text { After } \\
1 \text { month" } \\
12 \text { months } \\
6 \quad \text { " } \quad . \\
12 \quad \text { " } \quad .\end{array}$ & 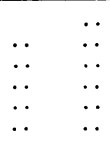 & $\begin{array}{l}26(31) \\
24(31) \\
27(31) \\
31(31) \\
26(34) \\
24(32)\end{array}$ & $\begin{array}{l}74(72) \\
72(72) \\
72(84) \\
76(86) \\
84(84) \\
82(84)\end{array}$ & $\begin{array}{l}56(52) \\
56(52) \\
64(64) \\
57(62) \\
60(57) \\
56(62)\end{array}$ & $\begin{array}{l}57(57) \\
55(57) \\
60(58) \\
60(60) \\
57(60) \\
57(57)\end{array}$ & $\begin{array}{l}29(22) \\
21(22) \\
24(24) \\
23(24) \\
26(26) \\
26(27)\end{array}$ \\
\hline
\end{tabular}

\begin{tabular}{|c|c|c|c|c|c|c|c|c|c|}
\hline \multicolumn{10}{|c|}{ Specimen 5} \\
\hline $\begin{array}{l}\text { Antigen Tes } \\
\text { Control }\end{array}$ & $\begin{array}{l}\text { sted and } \\
\text { ( ) }\end{array}$ & $\mathbf{H}(0)$ & $C\left(R_{1}^{W} r\right)$ & $C w\left(R_{1}^{\mathbb{w}} r\right)$ & $D\left(R_{1}^{w} r\right)$ & $\mathbf{M}(\mathrm{MM})$ & $\mathbf{P}_{1}\left(\mathbf{P}_{1}+++\right)$ & Kell* $(\mathbf{K}+)$ & Fye* $(F y *+)$ \\
\hline 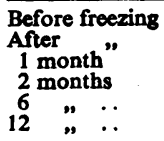 & $\begin{array}{l}\ldots \\
\cdots \\
\cdots \\
\cdots\end{array}$ & $\begin{array}{l}31(31) \\
31(31) \\
31(31) \\
32(31) \\
34(34) \\
31(32)\end{array}$ & $\begin{array}{l}40(45) \\
35(45) \\
34(40) \\
34(47) \\
35(50) \\
35(52)\end{array}$ & $\begin{array}{l}75(75) \\
72(75) \\
84(82) \\
77(77) \\
77(80) \\
77(77)\end{array}$ & $\begin{array}{l}77(84) \\
77(84) \\
77(80) \\
75(77) \\
82(80) \\
74(75)\end{array}$ & $\begin{array}{l}58(60) \\
57(60) \\
58(58) \\
57(60) \\
57(60) \\
53(57)\end{array}$ & $\begin{array}{l}31(21) \\
31(21) \\
26(24) \\
31(24) \\
27(26) \\
27(27)\end{array}$ & $\begin{array}{l}61(64) \\
61(64) \\
64(60) \\
66(62) \\
62(57) \\
62(60)\end{array}$ & $\begin{array}{l}66(66) \\
63(66) \\
56(56) \\
59(57) \\
66(56) \\
60(56)\end{array}$ \\
\hline
\end{tabular}

\begin{tabular}{|c|c|c|c|c|c|c|c|c|c|}
\hline \multicolumn{10}{|c|}{ Specimen 6} \\
\hline \multicolumn{2}{|c|}{$\begin{array}{l}\text { Antigen Tested and } \\
\text { Control ( ) }\end{array}$} & H (O) & $D\left(R_{8}^{n} r\right)$ & $D^{* *}\left(R_{2}^{u} t\right)$ & $E\left(R_{2}^{0} r\right)$ & $\mathbf{M}(\mathbf{M N})$ & $\mathrm{N}(\mathrm{MN})$ & $\mathbf{P}_{1}\left(\mathbf{P}_{1}+\right)$ & $\mathrm{Fy} *(\mathrm{Fy}++)$ \\
\hline $\begin{array}{l}\text { Before freezing } \\
\text { After } \\
1 \text { week ". } \\
3 \text { months } \\
6^{6} " . . \\
12 " . .\end{array}$ & $\begin{array}{ll}\cdots & \cdots \\
\cdots & \cdots \\
\cdots & \cdots \\
\cdots & \cdots\end{array}$ & $\begin{array}{l}26(31) \\
24(31) \\
22(31) \\
24(32) \\
24(34) \\
21(32)\end{array}$ & $\begin{array}{c}17(17) \\
14(17) \\
9(12) \\
7(12) \\
9(17) \\
4(9)\end{array}$ & $\begin{array}{l}52(46) \\
47(46) \\
50(54) \\
52(47) \\
50(47) \\
50(45)\end{array}$ & $\begin{array}{l}57(57) \\
52(57) \\
56(57) \\
62(60) \\
57(57) \\
57(62)\end{array}$ & $\begin{array}{l}57(57) \\
50(57) \\
53(55) \\
57(57) \\
57(58) \\
55(52)\end{array}$ & $\begin{array}{l}21(28) \\
19(28) \\
21(26) \\
29(29) \\
24(31) \\
23(23)\end{array}$ & $\begin{array}{l}14(11) \\
8(11) \\
8 \text { (11) } \\
8(8) \\
8(14) \\
4(11)\end{array}$ & $\begin{array}{l}66(66) \\
63(66) \\
64(66) \\
59(50) \\
61(56) \\
59(56)\end{array}$ \\
\hline
\end{tabular}

\begin{tabular}{|c|c|c|c|c|}
\hline \multicolumn{5}{|c|}{ Specimen 7} \\
\hline $\begin{array}{l}\text { Antigen Test } \\
\text { Control }\end{array}$ & & $\mathbf{H}(\mathbf{O})$ & $\bar{c}(\mathbf{r r})$ & $\mathrm{N}(\mathrm{NN})$ \\
\hline $\begin{array}{l}\text { Before freezing } \\
1 \text { month ... } \\
6 \text { " . }\end{array}$ & $\ddot{\ddot{*}}$ & $\begin{array}{l}29(32) \\
26(34) \\
31(32)\end{array}$ & $\begin{array}{l}76(77) \\
67(67) \\
62(65)\end{array}$ & $\begin{array}{l}33(36) \\
34(33) \\
31(31)\end{array}$ \\
\hline
\end{tabular}

All tests saline titrations except * Ant i-Globulin ("Coombs") Test and * Anti-Globulin Test with incomplete Anti-D. 
will show whether liquid nitrogen is not only more convenient but also more efficient than glycerol.

One red cell aldolase, one transaminase and two TPN dependent dehydrogenases have been measured in these blood samples before and after storage for various periods. The level of the aldolase, and to a lesser extent that of the transaminase, fell significantly during storage but the concentration of the dehydrogenases was maintained. These findings may have a bearing on the use for transfusion of blood stored by the present method.

The method reported is rather more expensive than the glycerol method but more convenient in use. In particular, the rate of loss of cells during storage is much reduced, and recovery of cells for use is much quicker. It is suggested that liquid nitrogen represents a suitable alternative to glycerol for the smaller laboratory, allowing them to have their own red cell panel readily available.

Thanks are due to Dr. A. Bracken, of the British Oxygen Company and to the Governors of St. Bartholomew's Hospital for arranging the regular supply of liquid nitrogen and to the Medical Research Council for providing the liguid-nitrogen storage cabinet.

\section{REPERENCES}

Bronson, W. R., and McGinniss, M. H. (1962). Blood, 20, 478 Bruns, F. (1954). Biochem. Z.. 325, is6.

Crawford. H., Cutbush, M., and Mollison, P. L. (1954). Vox Sung. (Basel). 4. 149.

Glock, G. E., and McLean, P. (1953). Biochem. J., 55, 400

Glock, G. E., and McLean, P. (1953). Biochem. J., 5s, 400. and Liddell, J. (1,02). J. clin. Puth. 15, 93.

- and Lehmann, $H$. (1960). Brit. med. J., 2, 118.

Hurn, B. A. L., Huntsman, R. G., and Lehmann, H. (1962). Transfusion, 2, 265.

Lehmann, H., and Hurn, B. A. L. (1961). In British Surgical Practice: Survical Progress, edited by Sir Ernest Rock Carling and Sir James Paterson Ross, p. 372. Butterworth, London.

Meryman, H. T., and Kafig, E. (1955). Proc. Soc. exp. Biol., 90, 587.

Race, R. R., and Sanger, R. (1950). Blood Groups in Man. Blackweil, Oxford.

Rapoport, S. (1961). Fol. haemat. (Lpz.). 78, 364.

Reitman, S., and Frankel, S. (1957). Amer. J. clin. Path., 28, 56. Reitman, S., and Frankel, S. (1957).

Smith, A. U. (1950). Lancet. 2, 910 Freezing and Supercooling. Arnold, London.

Strumia, M. M., Colwell, L. S., and Strumia, P. V. (1960). J. Lab. clin. Med., 56, 576.

\section{SERUM IMMUNO-CONGLUTININ IN MULTIPLE SCLEROSIS, HASHIMOTO'S DISEASE, AND RIIEUMATOID ARTHRITIS}

BY

\section{E. A. CASPARY, M.Sc.}

\author{
E. JANET BALL, B.Sc.
}

\section{From the M.R.C. Research Group on Demyelinating Diseases in the Department of Medicine, the Royal Victoria Infirmary, and King's College, Newcastle upon Tyne}

The titre of immuno-conglutinin in the serum rises after antigenic stimulation. While its role in the mechanism of immunity is not as yet understood, it is believed that the immuno-conglutinin response is a non-specific indicator of antigenic stimulation. Since there is a common belief that multiple sclerosis may fall within the category of "autoimmune" disease (Miller and Schapira, 1959) it was thought worth while investigating the serum and spinal fluid level of immuno-conglutinin at various stages of the disease and comparing these with those to be found in an accepted "autoimmune" disease such as Hashimoto's thyroiditis. Since cases of rheumatic disease also afford evidence of an altered immunological state (as shown by a positive RoseWaaler test) a series of such cases was also investigated.

\section{Materials and Methods}

Sera for testing, free from macroscopic haemolysis, were stored at $-20^{\circ} \mathrm{C}$. Complement was inactivated by heating to $56^{\circ} \mathrm{C}$. for 30 minutes, and the sera were then absorbed with $50 \%$ volume of packed washed sheep red cells $(0.25 \mathrm{ml}$. of packed cells to $0.5 \mathrm{ml}$. of serum) for 20 minutes at room temperature $\left(20^{\circ} \mathrm{C}\right.$.).

Sheep red cells and bovine and horse serum were freshly obtained from a slaughterhouse. Early experimental results were found not to be reproducible, and it was only when fresh sheep erythrocytes (not more than one week old) and fresh bovine and horse sera were used that a standardized and reliable method was evolved.

Immuno-conglutinin was titrated by the method of Coombs, Coombs, and Ingram (1961). To $0.1 \mathrm{ml}$. of doubling dilutions of serum in saline was added $0.1 \mathrm{ml}$. of alexinated cells and $0.1 \mathrm{ml}$. of saline. The tubes were then incubated at $37^{\circ} \mathrm{C}$. for 30 minutes, spun lightly, and read macroscopically in the manner suggested by Coombs et al. after resuspending in the supernatant fluid. The end-point was taken as the last tube showing discrete visible agglutination. Negative controls using alexinated cells, prepared with inactivated horse serum only, were put up with each serum to eliminate error due to nonspecific clumping.

Alexinated cells were prepared as follows. Sheep red cells were first sensitized with bovine antibody by incubating equal volumes of a $5 \%$ suspension and a $1: 2$ dilution of heat-inactivated bovine serum ( 30 minutes at $56^{\circ} \mathrm{C}$.) at $37^{\circ} \mathrm{C}$. for 15 minutes. This suspension was centrifuged, washed once in saline, and suspended in saline to give a $5 \%$ suspension. Red-cell concentrations were prepared by accurate dilution from a stock suspension of known packed cell volume.

Alexination was then carried out as follows: $2 \mathrm{ml}$. of the above suspension sensitized cells, $2 \mathrm{ml}$. of horse serum complement, $2 \mathrm{ml}$. of heat-inactivated horse serum, and $14 \mathrm{ml}$. of saline were mixed and incubated at $37^{\circ} \mathrm{C}$. for 15 minutes. This suspension of cells was used without washing, and in our hands proved stable and not liable to non-specific agglutination.

\section{Results}

Sera from 43 normal blood donors, collected over the same period as the pathological sera, were used as controls. The distribution of immuno-conglutinin titre is shown in Fig. A.; the statistical significance of results is set out in the Table.

Sera from 27 cases of multiple sclerosis which fall into two groups-chronic cases seen at follow-up examinations; and new cases presenting in an acute episode and where a confident clinical diagnosis could be madewere distributed very similarly to the normal (Figs. B 